\title{
Pemodelan dan Pemetaan Jumlah Penderita Kusta di Jawa Barat dengan Regresi Binomial Negatif dan Flexibly Shaped Spatial Scan \\ Statistic
}

\author{
Luhung Mustika Budiharti* \\ Prodi Statistika, Fakultas Matematika dan Ilmu Pengetahuan Alam, \\ Universitas Islam Bandung, Indonesia. \\ *luhungbudiharti02@gmail.com
}

\begin{abstract}
Flexibly Shaped Spatial Scan Statistics is a statistical scan method used to detect hotspots in a location in the form of points or aggregates. This method will be more flexible to the shape of the resulting hotspot. The hotspot detection process with this method requires forecast data for each region. The forecast data was obtained with the best modeling between poisson regression and negative binomial regression. In the Poisson regression method there are assumptions that must be met, namely the mean and variance of the response variables must be the same. In fact, in the count data this assumption is often not fulfilled because of overdispersion problems. The negative binomial distribution is an unusual statistical model, this distribution can adjust for the overdispersion problem in the poisson distribution. Therefore, the overdispersion problem in poisson regression modeling can be overcome by negative binomial regression. This study uses secondary data on the number of leprosy sufferers in West Java in 2019. Leprosy is a disease caused by the bacterium Mycobacterium leprae. According to the 2019 Health Service Report, West Java is the second province with the highest number of new cases of leprosy in Indonesia. The results of this study indicate that there were 2 leprosy hotspots in West Java in 2019.
\end{abstract}

Keywords: Flexibly Shaped Spatial Scan Statistic, Regresi Poisson, Regresi Binomial Negatif, Kusta.

\begin{abstract}
Abstrak. Flexibly Shaped Spatial Scan Statistic merupakan salah satu metode scan statistic yang digunakan untuk mendeteksi wilayah kantong (hotspot) di sebuah lokasi yang berupa titik atau agregat. Metode ini akan lebih fleksibel terhadap bentuk hotspot yang dihasilkan. Proses pendeteksian hotspot dengan metode ini membutuhkan data ramalan untuk setiap wilayah. Data ramalan tersebut diperoleh dengan pemodelan terbaik diantara regresi poisson dan regresi binomial negatif. Dalam metode regresi poisson terdapat asumsi yang harus dipenuhi yaitu nilai mean dan variance variabel respon harus sama. Kenyataanya pada data count asumsi ini sering tidak terpenuhi karena terjadi masalah overdispersi. Distribusi binomial negatif merupakan model statistik yang tidak biasa, distribusi ini dapat menyesuaikan adanya masalah overdispersi pada distribusi poisson.Oleh karena itu, masalah overdispersi dalam pemodelan regresi poisson dapat diatasi dengan regresi binomial negatif. Pada penelitian ini digunakan data sekunder Jumlah Penderita Kusta di Jawa Barat Tahun 2019. Kusta merupakan penyakit yang disebabkan oleh bakteri Mycobacterium leprae. Menurut Laporan Dinas Kesehatan tahun 2019, Jawa Barat merupakan provinsi kedua dengan jumlah kasus baru kusta terbanyak di Indonesia. Hasil pada penelitian ini menunjukkan adanya 2 hotspot kusta di Jawa Barat pada tahun 2019
\end{abstract}

Kata Kunci: Flexibly Shaped Spatial Scan Statistic, Regresi Poisson, Regresi Binomial Negatif, Kusta. 


\section{A. Pendahuluan}

Metode Flexibly Shaped Spatial Scan Statistic diusulkan oleh Toshiro Tango dan Kunihiko Takashi pada tahun 2005. Berbeda dengan metode Scan Statistic sebelumnya, metode ini mempunyai akurasi lebih tinggi ketika cluster yang dideteksi adalah non-circular dan fleksibel terhadap bentuk kantong yang dihasilkan sehingga tidak terbatas pada bentuk lingkaran saja (Tango dan Takashi, 2005). Pendeteksian hotspot dengan metode Flexibly Shaped Spatial Scan Statistic membutuhkan nilai ramalan untuk setiap wilayah berdasarkan faktor-faktor yang diduga mempengaruhinya. Ramalan tersebut diperoleh dengan pemodelan melalui analisis regresi.

Metode yang dapat digunakan untuk pemodelan jumlah penderita kusta dan faktorfaktor yang diduga mempengaruhinya adalah regresi poisson. Pada regresi poisson terdapat asumsi yang harus dipenuhi yaitu nilai mean dan variance dari variabel respon harus sama. Namun, asumsi tersebut jarang terpenuhi karena pada data count biasanya mempunyai variance yang lebih besar daripada mean. Menurut Cameron dan Trivedi (1998) kondisi variance yang lebih besar daripada mean ini disebut dengan overdispersi. Masalah overdispersi menyebabkan nilai penaksir simpangan baku koefisien regresi terlalu kecil, sehingga nilai statistik uji dalam pengujian hipotesis menjadi lebih besar dan menjadikan variabel prediktor terlalu mudah untuk dianggap mempunyai pengaruh terhadap variabel respon. Salah satu metode yang dapat digunakan untuk mengatasi overdispersi pada regresi poisson adalah regresi binomial negatif. Menurut Hilbe (2011) regresi binomial negatif adalah salah satu model regresi terapan dari Generalized Linear Model (GLM) dan termasuk anggota dari keluarga eksponensial.

Pada penelitian ini digunakan data jumlah penderita kusta di provinsi Jawa Barat pada tahun 2019. Kusta merupakan penyakit yang disebabkan oleh bakteri Mycobacterium leprae. Penyakit ini akan mempengaruhi kulit, saraf tepi, mukosa saluran pernafasan atas dan mata. Bakteri Mycobacterium leprae dapat menular melalui percikan cairan saluran pernapasan. Penularan berlangsung sangat sulit dan membutuhkan waktu yang lama. Kusta jenis Pausibasiler (PB) akan menyerang satu saraf. Sedangkan kusta jenis Multibasiler (MB) akan menyerang banyak cabang saraf. Kurangnya kesadaran masyarakat terhadap adanya penyakit kusta menjadikan kusta termasuk kelompok penyakit tropis yang terabaikan (neglected tropical disease).

Pada tahun 2019, Indonesia menjadi negara ketiga di dunia dengan kasus baru kusta terbanyak dalam waktu satu tahun (Kemenkes, 2019). Jawa Barat merupakan provinsi yang berada di peringkat dua dengan jumlah penderita kusta tertinggi di Indonesia (Dinkes Jawa Barat, 2019). Dinas Kesehatan Jawa Barat melaporkan ada sebanyak 2.101 kasus baru kusta pada tahun 2019, dimana 90\% diantaranya merupakan kusta tipe Multibasiler (MB). Total penderita kusta yang terdaftar di Jawa Barat pada tahun 2019 adalah 2.294 orang dengan prevalensi 0,47 kasus per 10.000 penduduk. Penanganan yang lambat pada kusta dapat menyebabkan dampak buruk bagi penderita seperti mengalami kerusakan permanen (cacat) pada kulit, saraf, anggota gerak, dan mata. Salah satu upaya mengurangi kasus kusta adalah dengan mendeteksi hotspot yang mempunyai resiko tinggi terkena kusta, sehingga pencegahan dan penanggulangan dapat dilakukan lebih efektif, efisien, dan tepat sasaran .

Berdasarkan latar belakang yang telah diuraikan, maka perumusan masalah dalam penelitian ini adalah: "Bagaimana pemodelan dan pemetaan hotspot jumlah penderita kusta di Jawa Barat pada tahun 2019?". Selanjutnya, tujuan dari penelitian ini diuraikan sebagai berikut:

1. Mengetahui pemodelan jumlah penderita kusta di Jawa Barat pada tahun 2019.

2. Melakukan pemetaan wilayah kantong (hotspot) jumlah penderita kusta berdasarkan Kabupaten/Kota di Jawa Barat pada tahun 2019.

\section{B. Metodologi Penelitian \\ Data dan Sumber Data}

Data diperoleh dari Dinas Kesehatan dan Badan Pusat Statistik (BPS) Provinsi Jawa Barat. Unit penelitian yang digunakan adalah 27 Kabupaten/Kota. Variabel respon (Y) pada penelitian ini adalah jumlah penderita kusta, sedangkan variabel prediktor $(\mathrm{X})$ terdiri dari:

$$
\mathrm{X}_{1} \text { : Jumlah rumah tangga ber-Perilaku Hidup Bersih dan Sehat (PHBS) }
$$


$\mathrm{X}_{2}$ : Persentase penduduk laki-laki

$\mathrm{X}_{3}$ : Jumlah rumah tangga tidak mempunyai fasilitas tempat buang air besar

$\mathrm{X}_{4}$ : Persentase penduduk dengan akses air minum layak

$\mathrm{X}_{5}$ : Tingkat kepadatan penduduk

$\mathrm{X}_{6}$ : Persentase penduduk miskin

\section{Prosedur Penelitian}

Pada awalnya, pemodelan dilakukan dengan regresi poisson. Menurut Agresti (2002) regresi poisson merupakan salah satu metode Generalized Linear Models (GLM) paling sederhana untuk data count. Selanjutnya, pemodelan dilakukan dengan regresi binomial negatif. Variabel respon (Y) pada regresi binomial negatif dihasilkan dari distribusi campuran Poisson-Gamma yang dapat mengatasi overdispersi pada regresi poisson (McCullagh dan Nelder, 1989). Berikut ini langkah-langkah pemodelan yang dilakukan:

1. Mendeteksi masalah multikolinieritas. Menurut Ridwan dan Sunendiari (2021) multikolinieritas dapat dilihat dengan nilai Variance Inflation Factor (VIF) sebaga berikut:

$$
V I F=\frac{1}{1-R_{j}^{2}}
$$

2. Penaksiran parameter model regresi poisson dengan metode Maximum Likelihood Estimator (MLE). Berikut ini model regresi poisson:

$$
\hat{\mu}_{i}=\exp \left(\beta_{0}+\beta_{1} x_{i 1}+\beta_{2} x_{i 2}+\beta_{3} x_{i 3}+\cdots+\beta_{k} x_{i k}\right)
$$

3. Mendeteksi adanya masalah overdispersi pada regresi poisson:

$$
\begin{array}{r}
D=-2 \ln \left(\frac{L(\widehat{\omega})}{L(\widehat{\Omega})}\right) \\
\theta=\frac{D}{d b} \text { dimana, } d b=n-p
\end{array}
$$

Jika nilai dari $\theta$ lebih dari 1 , maka dapat disimpulkan adanya overdispersi pada data.

4. Penaksiran parameter model regresi binomial negatif dengan metode Maximum Likelihood Estimator (MLE). Berikut ini model regresi binomial negatif:

$$
\hat{\mu}_{i}=\exp \left(\beta_{0}+\beta_{1} x_{i 1}+\beta_{2} x_{i 2}+\beta_{3} x_{i 3}+\cdots+\beta_{k} x_{i k}\right)
$$

5. Memilih model terbaik. Salah satu metode yang dapat menentukan model terbaik adalah Akaike Information Criteria (AIC) (Herdiani dan Amran, 2007). Nilai AIC dinyatakan sebagai berikut:

$$
A I C=-2 \ln L(\hat{\beta})+2 k
$$

6. Membuat prediksi jumlah penderita kusta $\left(\hat{y}_{i}\right)$ berdasarkan model terbaik.

Selanjutnya, untuk pendeteksian hotspot digunakan metode Flexibly Shaped Spatial Scan Statistic. Pada awalnya suatu daerah dibagi menjadi $n$ daerah. Jumlah kasus di setiap wilayah $i$ dilambangkan dengan $Y_{i}$. Berikut ini langkah-langkah pendeteksian hotspot:

1. Mengambil data prediksi jumlah penderita kusta $\left(\hat{y}_{i}\right)$. Selain itu, dilakukan pengambilan data spasial berupa titik koordinat latitude dan longitude.

2. Mengidentifikasi hotspot dengan algoritma yang ada di metode Flexibly Shaped Spatial Scan Statistic. Himpunan hotspot tersebut dinyatakan sebagai berikut:

$$
Z=\left\{Z_{i l(m)} \mid 1 \leq i \leq n, 1 \leq l \leq L, 1 \leq m \leq m_{i l}\right\}
$$

3. Menetapkan maximum number yang digunakan $(L)$.

4. Menghitung nilai harapan jumlah pederita kusta dan jumlah penderita kusta real untuk setiap hotspot.

5. Menghitung log likelihood function dari setiap hotspot dan menguji signifikansi hotspot dengan simulasi Monte Carlo. Nilai $p$-value dinyatakan sebagai berikut:

$$
p=\frac{\text { banyaknya }\left(T(y) \geq t_{0}\right)}{m+1}
$$

$\mathrm{t}_{0}$ menyatakan penjumlahan nilai log likelihood ratio tertinggi yang dimiliki suatu window $\mathrm{Z}$ dari data rill. $T(y)$ adalah penjumlahan nilai log likelihood ratio dari data acak, dan $m$ adalah banyaknya simulasi. Jika $\mathrm{p}$-value $<\alpha$ maka $\mathrm{H}_{0}$ ditolak yang berarti 
bahwa window $\mathrm{Z}$ adalah hotspot yang signifikan.

6. Menghitung resiko relatif setiap hotspot.

7. Membuat peta hotspot kusta di Jawa Barat berdasarkan hotspot yang signifikan pada $\alpha$ $=0,05$.

8. Menginterpretasikan hasil dengan membuat deskripsi hotspot kusta.

\section{Hasil Penelitian dan Pembahasan}

Pemeriksaan Multikolinieritas

Berikut adalah nilai VIF dari setiap variabel prediktor:

Tabel 1 Nilai VIF Variabel Prediktor

\begin{tabular}{|l|l|l|l|l|l|l|}
\hline Variabel & $\mathrm{X}_{1}$ & $\mathrm{X}_{2}$ & $\mathrm{X}_{3}$ & $\mathrm{X}_{4}$ & $\mathrm{X}_{5}$ & $\mathrm{X}_{6}$ \\
\hline VIF & 3,532 & 1,474 & 3,384 & 1,795 & 3,845 & 3,227 \\
\hline
\end{tabular}

Tabel 1 merupakan nilai VIF dari masing-masing variabel prediktor. Jika nilai VIF lebih besar dari 10 maka menunjukkan adanya masalah multikolinieritas. Pada Tabel 1 dapat diketahui bahwa nilai VIF dari enam variabel prediktor bernilai kurang dari 10, maka dapat disimpulkan tidak terjadi kasus multikolinieritas diantara variabel prediktor.

\section{Pemodelan Jumlah Penderita Kusta Menggunakan Regresi Poisson}

Setelah dipastikan tidak ada masalah multikolinieritas diantara variabel prediktor, maka dilanjutkan dengan pemodelan regresi poisson. Pemodelan dilakukan dengan bantuan software R. Berikut ini adalah hasil estimasi parameter model regresi poisson dengan menggunakan metode Maximum Likelihood Estimation (MLE):

Tabel 2 Estimasi Parameter Resgresi Poisson

\begin{tabular}{cllll}
\hline Parameter & \multicolumn{1}{c}{ Estimasi } & Standart Error & \multicolumn{1}{c}{ Zhitung $_{\text {P-value }}$} & \multicolumn{1}{c}{ P-18, } \\
$\beta_{0}$ & $-57,93$ & 3,151 & $-18,384$ & $<2 \times 10^{-16}$ \\
$\beta_{1}$ & $2,608 \times 10^{-6}$ & $3,210 \times 10^{-7}$ & 8,124 & $4,51 \times 10^{-16}$ \\
$\beta_{2}$ & 1,225 & $6,310 \times 10^{-2}$ & 19,418 & $<2 \times 10^{-16}$ \\
$\beta_{3}$ & $5,466 \times 10^{-6}$ & $1,270 \times 10^{-6}$ & 4,303 & $1,69 \times 10^{-5}$ \\
$\beta_{4}$ & $-1,282 \times 10^{-2}$ & $1,559 \times 10^{-3}$ & $-8,221$ & $<2 \times 10^{-16}$ \\
$\beta_{5}$ & $7,180 \times 10^{-5}$ & $1,072 \times 10^{-5}$ & 6,696 & $2,14 \times 10^{-11}$ \\
$\beta_{6}$ & $1,224 \times 10^{-2}$ & $2,131 \times 10^{-2}$ & 0,575 & 0,565 \\
\hline Devians & 1413 & & $\mathrm{df}=20$ & \\
AIC & 1558,8 & & & \\
\hline
\end{tabular}

Berdasarkan Tabel 2 diketahui nilai devians sebesar 1413. Dengan taraf signifikan 10\% didapatkan nilai $\chi_{(0.1 ; 6)}^{2}$ sebesar 10,6. Jika dibandingkan, nilai devians lebih besar dari nilai $\chi_{(0.1 ; 6)}^{2}$, sehingga diperoleh keputusan tolak $\mathrm{H}_{0}$. Hal ini mempunyai arti bahwa paling sedikit ada satu variabel prediktor yang berpengaruh terhadap jumlah penderita kusta di Jawa Barat. Selanjutnya dilakukan pengujian secara parsial untuk mengetahui variabel prediktor mana saja yang mempengaruhi jumlah kasus kusta di Jawa Barat. Nilai $\left|Z_{\text {hitung }}\right|$ dibandingkan dengan nilai $\mathrm{Z}_{\text {tabel }}$, dengan taraf signifikan $10 \%$ diperoleh nilai $\mathrm{Z}_{(0.1 / 2)}$ sebesar 1,64 . Pada Tabel 2 menunjukkan bahwa nilai $\left|Z_{\text {hitung }}\right|$ dari lima parameter mempunyai nilai lebih besar dari 1,64. Sedangkan pada variabel $\mathrm{X}_{6}$ mempunyai nilai $\left|\mathrm{Z}_{\mathrm{hitung}}\right|$ kurang dari 1,64. Maka dapat disimpulkan bahwa pada model regresi poisson variabel persentase penduduk miskin tidak mempunyai pengaruh yang signifikan terhadap jumlah penderita kusta di Jawa Barat. Sedangkan lima variabel prediktor lainnya secara parsial mempunyai pengaruh yang signifikan terhadap jumlah penderita kusta di Jawa Barat. Berikut ini model regresi poisson yang diperoleh:

$\hat{\mu}=\exp \left(-57,93+0,0000026 X_{1}+1,225 X_{2}+0,00000546 X_{3}-0,0128 X_{4}+0,0000718 X_{5}\right.$

$$
\left.+0,01224 X_{6}\right)
$$


Berdasarkan model regresi poisson diatas dapat diketahui bahwa setiap pertambahan 1 rumah tangga ber-PHBS $\left(\mathrm{X}_{1}\right)$, maka akan meningkatkan rata-rata jumlah penderita kusta sebanyak $\exp (0,0000026) \approx 1$ penderita kusta dengan syarat variabel lain konstan. Setiap pertambahan 1 persen penduduk laki-laki $\left(\mathrm{X}_{2}\right)$ maka akan meningkatkan rata-rata jumlah penderita kusta sebanyak $\exp (1,225) \approx 3$ penderita kusta dengan syarat variabel lain konstan. Setiap pertambahan 1 rumah tangga yang tidak mempunyai fasilitas tempat buang air besar $\left(\mathrm{X}_{3}\right)$ maka akan meningkatkan rata-rata jumlah penderita kusta sebanyak $\exp (0,0000546) \approx 1$ penderita kusta dengan syarat variabel lain konstan. Setiap pertambahan 1 persen penduduk dengan akses air minum layak $\left(\mathrm{X}_{4}\right)$ maka akan menurunkan rata-rata jumlah penderita kusta di Jawa Barat sebanyak exp(-0.01282) $\approx 1$ penderita kusta, dengan syarat variabel lain konstan. Setiap pertambahan 1 satuan tingkat kepadatan penduduk $\left(\mathrm{X}_{5}\right)$ maka akan meningkatkan ratarata jumlah penderita kusta sebanyak $\exp (0,0000718) \approx 1$ penderita kusta dengan syarat variabel lain konstan, dan setiap pertambahan 1 persen penduduk miskin $\left(\mathrm{X}_{6}\right)$ maka akan meningkatkan rata-rata jumlah penderita kusta sebanyak $\exp (0,01224) \approx 1$ penderita kusta dengan syarat variabel lain konstan.

\section{Pemeriksaan Overdispersi}

Asumsi yang harus dipenuhi pada regresi poisson adalah nilai mean dan variance dari variabel respon harus sama, kondisi ini disebut juga dengan equidispersi. Mendeteksi adanya overdispersi pada regresi poisson dapat dilakukan dengan membagi nilai devians dengan derajat bebasnya (devians/db). Jika nilai devians/db lebih besar dari 1 maka dapat dikatakan terjadi overdispersi.

Tabel 3 Uji Overdispersi Regresi Poisson

\begin{tabular}{|c|c|c|}
\hline Devians & Db & Devians/db \\
\hline 1413 & 20 & 70,65 \\
\hline
\end{tabular}

Berdasarkan Tabel 3 dapat diketahui bahwa nilai devians/db dari model regresi poisson mempunyai nilai lebih dari 1, sehingga dapat disimpulkan pada data jumlah penderita kusta di Jawa Barat tahun 2019 terjadi overdispersi. Untuk mengatasi masalah overdispersi ini, metode yang dapat digunakan adalah regresi Binomial Negatif.

\section{Pemodelan Jumlah Penderita Kusta Mengunakan Regresi Binomial Negatif}

Model regresi binomial negatif diperoleh dengan bantuan software R. Berikut ini adalah hasil estimasi parameter model regresi binomial negatif dengan metode Maximum Likelihood Estimation (MLE):

Tabel 4 Estimasi Parameter Resgresi Binomial Negatif

\begin{tabular}{cllll}
\hline Parameter & \multicolumn{1}{c}{ Estimasi } & \multicolumn{1}{c}{ Standart Error } & $\mathbf{Z}_{\text {hitung }}$ & P-value \\
\hline$\beta_{0}$ & $-51,27$ & 23,96 & $-2,139$ & 0,0324 \\
$\beta_{1}$ & $2,317 \times 10^{-6}$ & $2,890 \times 10^{-6}$ & 0,802 & 0,4227 \\
$\beta_{2}$ & 1,059 & 0,4869 & 2,174 & 0,0297 \\
$\beta_{3}$ & $1,591 \times 10^{-5}$ & $1,458 \times 10^{-5}$ & 1,091 & 0,2752 \\
$\beta_{4}$ & $-4,867 \times 10^{-3}$ & $1,582 \times 10^{-2}$ & $-0,308$ & 0,7583 \\
$\beta_{5}$ & $1,229 \times 10^{-4}$ & $9,100 \times 10^{-5}$ & 1,351 & 0,1767 \\
$\beta_{6}$ & 0,1109 & 0,1637 & 0,678 & 0,4980 \\
\hline Devians & $=32,453$ & & $\mathrm{df}=20$ & \\
AIC & $=280,78$ & & & \\
\hline
\end{tabular}

Berdasarkan Tabel 4 hasil analisis menunjukkan nilai devians sebesar 32,453. Dengan taraf signifikan $10 \%$ didapatkan nilai $\chi_{(0.1 ; 6)}^{2}$ sebesar 10,6. Jika dibandingkan, nilai devians lebih besar dari nilai $\chi_{(0.1 ; 6)}^{2}$, sehingga diperoleh keputusan tolak $\mathrm{H}_{0}$. Hal ini mempunyai arti bahwa pada model regresi binomial negatif paling sedikit ada satu variabel prediktor yang berpengaruh terhadap jumlah penderita kusta di Jawa Barat. Selanjutnya, dilakukan pengujian secara parsial untuk mengetahui variabel prediktor mana saja yang berpengaruh terhadap jumlah penderita JRS is licensed under Creative Commons Attribution- 
kusta di Jawa Barat. Pengujian secara parsial ini dilakukan dengan melihat nilai $\left|Z_{\text {hitung }}\right|$ pada setiap parameter. Nilai $\left|Z_{\text {hitung }}\right|$ kemudian dibandingkan dengan nilai $Z_{\text {tabel }}$, dengan menggunakan taraf signifikan $10 \%$ diperoleh nilai $\mathrm{Z}_{(0.1 / 2)}$ sebesar 1,64 . Pada Tabel 4 menunjukkan bahwa hanya variabel persentase penduduk laki-laki $\left(\mathrm{X}_{2}\right)$ yang mempunyai nilai $\left|\mathrm{Z}_{\mathrm{hitung}}\right|$ lebih besar dari 1,64. Maka dapat disimpulkan bahwa pada model regresi binomial negatif, hanya variabel persentase penduduk laki-laki yang signifikan memberikan pengaruh terhadap jumlah penderita kusta di Jawa Barat. Berikut ini model regresi binomial negatif:

$$
\begin{gathered}
\hat{\mu}=\exp \left(-51,27+0,000002317 X_{1}+1,059 X_{2}+0,0000159 X_{3}-0,004867\right. \\
\left.+0,0001229 X_{5}+0,1109 X_{6}\right)
\end{gathered}
$$

Dari model regresi binomial negatif diatas dapat diketahui bahwa setiap pertambahan 1 rumah tangga ber-PHBS $\left(\mathrm{X}_{1}\right)$, maka akan meningkatkan rata-rata jumlah penderita kusta sebanyak $\exp (0,000002317) \approx 1$ penderita kusta dengan syarat variabel lain konstan. Setiap pertambahan 1 persen penduduk laki-laki $\left(\mathrm{X}_{2}\right)$ maka akan meningkatkan rata-rata jumlah penderita kusta sebanyak $\exp (1,059) \approx 3$ penderita kusta dengan syarat varibel lain konstan. Setiap pertambahan 1 rumah tangga yang tidak mempunyai fasilitas tempat buang air besar $\left(\mathrm{X}_{3}\right)$ maka akan meningkatkan rata-rata jumlah penderita kusta sebanyak $\exp (0,0000159) \approx 1$ penderita kusta dengan syarat varibel lain konstan. Setiap pertambahan 1 persen penduduk dengan akses air minum layak $\left(\mathrm{X}_{4}\right)$ maka akan menurunkan rata-rata jumlah penderita kusta di Jawa Barat sebesar exp $(-0,004867) \approx 1$ penderita kusta dengan syarat varibel lain konstan. Setiap pertambahan 1 satuan tingkat kepadatan penduduk $\left(\mathrm{X}_{5}\right)$ maka akan meningkatkan ratarata jumlah penderita kusta sebanyak $\exp (0,0001229) \approx 1$ penderita kusta dengan syarat varibel lain konstan, dan setiap pertambahan 1 persen penduduk miskin $\left(\mathrm{X}_{6}\right)$ maka akan meningkatkan rata-rata jumlah penderita kusta sebanyak $\exp (0,1109) \approx 1$ penderita kusta dengan syarat variabel lain konstan.

\section{Pemilihan Model Terbaik}

Setelah melakukan pemodelan dengan regresi poisson dan regresi binomial Negatif, dilakukan perbandingan diantara kedua model tersebut untuk mengetahui model terbaik dari pemodelan jumlah penderita kusta di Jawa Barat tahun 2019. Pemilihan model terbaik dilihat dari nilai AIC. Model terbaik adalah model yang mempunyai nilai AIC terkecil diantara model lainnya. Berikut ini nilai AIC yang diperoleh:

Tabel 5 Pemilihan Model Terbaik

\begin{tabular}{|l|l|c|}
\hline \multicolumn{1}{|c|}{ Model } & \multicolumn{1}{c|}{ Variabel Signifikan } & Nilai AIC \\
\hline Regresi Poisson & $\mathrm{X}_{1} \mathrm{X}_{2} \mathrm{X}_{3} \mathrm{X}_{4} \mathrm{X}_{5}$ & 1558,8 \\
\hline Regresi Binomial Negatif & $\mathrm{X}_{2}$ & 280,78 \\
\hline
\end{tabular}

Berdasarkan Tabel 5 model regresi binomial negatif mempunyai nilai AIC terkecil. Oleh karena itu, dapat disimpulkan bahwa model terbaik untuk jumlah penderita kusta di Jawa Barat tahun 2019 adalah model regresi binomial negatif. Selanjutnya dilakukan peramalan jumlah penderita kusta di Jawa Barat dengan menggunakan model regresi binomial negatif.

\section{Pendeteksian Hotspot Jumlah Penderita Kusta di Jawa Barat}

Untuk mendeteksi hotspot jumlah penderita kusta di Jawa Barat digunakan metode Flexibly Shaped Spatial Scan Statistic. Pendeteksian ini dilakukan dengan bantuan software Flexscan v3.2.1. Data prediksi dari model regresi binomial negatif digunakan untuk pendeteksian hotspot jumlah penderita kusta di Jawa Barat pada tahun 2019. Jumlah Kabupaten/Kota untuk setiap hotspot dibatasi 15 Kabupaten/Kota saja yang berbatasan dengan jarak terdekat. Pengujian signifikan dilakukan dengan simulasi Monte Carlo dengan pengulangan 9999. Berikut ini hasil pendeteksian hotspot jumlah pederita kusta di Jawa Barat pada Tahun 2019:

Tabel 6 Hotspot Kusta dengan Pemodelan Regresi Binomial Negatif

\begin{tabular}{|c|c|c|c|c|c|}
\hline $\begin{array}{c}\text { Hotspot } \\
\text { Kusta }\end{array}$ & Kabupaten/Kota & $\begin{array}{c}\text { Kasus } \\
\text { Kusta }\end{array}$ & Harapan & $\begin{array}{c}\text { Resiko } \\
\text { Relatif }\end{array}$ & P-value \\
\hline 1 & 1 & 194 & 43,1507 & 4,49587 & 0,0001 \\
\hline
\end{tabular}




\begin{tabular}{|c|c|c|c|c|c|}
\hline 2 & & 1407 & 854,21 & 1,64714 & 0,0001 \\
\hline \multicolumn{6}{|c|}{ Keterangan : } \\
\hline Hotspot Kusta & $=$ & \multicolumn{4}{|c|}{$\begin{array}{l}\text { Kumpulan satu atau beberapa Kabupaten/Kota } \\
\text { yang membentuk hotspot kusta di Jawa Barat. }\end{array}$} \\
\hline Kabupaten/Kota & $=$ & \multicolumn{4}{|c|}{ Jumlah Kabupaten/Kota dalam satu hotspot. } \\
\hline Kasus Kusta & $=$ & $\begin{array}{l}\text { Jumlah } \\
\text { hotspo }\end{array}$ & \multicolumn{3}{|c|}{ total penderita kusta dalam satu } \\
\hline Harapan & $=$ & \multicolumn{4}{|c|}{$\begin{array}{l}\text { Jumlah kasus kusta yang diharapkan dalam satu } \\
\text { hotspot. }\end{array}$} \\
\hline Resiko relatif & $=$ & \multicolumn{4}{|c|}{$\begin{array}{l}\text { Nilai resiko relatif di dalam hotspot kusta } \\
\text { dibanding dengan nilai resiko relatif di luar } \\
\text { hotspot. }\end{array}$} \\
\hline$P$-value & $=$ & \multicolumn{4}{|c|}{$\begin{array}{l}\text { Perbandingan antara likelihood yang maksimal } \\
\text { dari data sebenarnya dibandingkan dengan } \\
\text { likelihood acak. }\end{array}$} \\
\hline
\end{tabular}

Pendeteksi hotspot kusta di Jawa Barat dengan metode flexibly shaped spatial scan statistic menghasilkan 2 hotspot. Berikut ini adalah peta hotspot kusta di Jawa Barat pada tahun 2019:

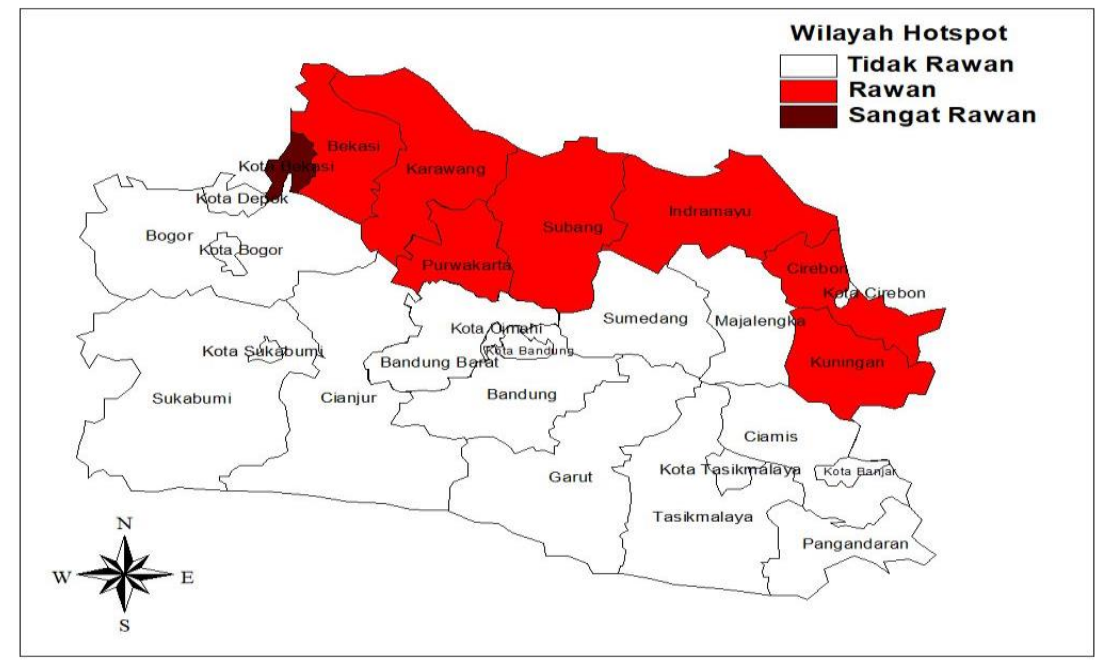

Gambar 1 Peta Hotspot Kusta di Jawa Barat

Berdasarkan Gambar 1 dapat diketahui daerah yang berwarna merah tua merupakan Kota Bekasi, dimana Kota Bekasi menjadi daerah yang sangat rawan terkena kusta. Dapat dilihat pada Tabel 6 Kota Bekasi mempunyai resiko ditemukannya penderita kusta 4,49587 kali lebih tinggi dibandingkan dengan daerah lain. Selanjutnya daerah yang berwarna merah muda terdiri dari tujuh daerah yaitu Kabupaten Kuningan, Kabupaten Cirebon, Kabupaten Indramayu, Kabupaten Subang, Kabupaten Purwakarta, Kabupaten Karawang, dan Kabupaten Bekasi. Daerah tersebut tergolong daerah yang rawan terkena kusta. Dapat dilihat pada Tabel 6, tujuh daerah ini mempunyai resiko ditemukannya penderita kusta 1,64714 kali lebih tinggi dibandingkan dengan daerah lain yang berada diluar hotspot. Sedangkan daerah yang berwarna putih merupakan daerah yang tidak termasuk zona rawan terkena kusta. Daerah yang termasuk zona tidak rawan terdiri dari 19 Kabupaten/Kota yang belum disebutkan.

\section{Kesimpulan}

Berdasarkan hasil analisis dan pembahasan yang telah dilakukan, peneliti menyimpulkan 
beberapa hasil penelitian sebagai berikut:

1. Hasil pemodelan regresi poisson menunjukkan adanya masalah overdispersi. Berdasarkan nilai AIC model regresi binomial negatif merupakan model terbaik. Pada model regresi Binomial Negatif diketahui hanya variabel persentase penduduk laki-laki yang memberikan pengaruh terhadap jumlah penderita kusta di Jawa Barat pada tahun 2019. Berikut model regresi Binomial Negatif yang diperoleh:

$$
\begin{gathered}
\hat{\mu}=\exp \left(-51,27+0,000002317 X_{1}+1,059 X_{2}+0,0000159 X_{3}-0,004867\right. \\
\left.+0,0001229 X_{5}+0,1109 X_{6}\right)
\end{gathered}
$$

2. Pendeteksian hotspot kusta dengan pendekatan metode Flexibly Shaped Spatial Scan Statistic dihasilkan 2 hotspot kusta. Hotspot pertama adalah Kota Bekasi yang mempunyai resiko 4,49587 kali lebih besar dibandingkan dengan daerah lainnya. Hotspot kedua adalah Kabupaten Kuningan, Kabupaten Cirebon, Kabupaten Indramayu, Kabupaten Subang, Kabupaten Purwakarta, Kabupaten Karawang, dan Kabupaten Bekasi yang termasuk daerah rawan terkena kusta dengan resiko 1,64714 kali lebih tinggi dibandingkan dengan daerah lainnya.

\section{Acknowledge}

Puji dan syukur penulis panjatkan kehadirat Allah SWT, yang telah melimpahkan rahmat dan hidayah-Nya sehingga penulis dapat menyelesaikan penelitian ini. Terimakasih kepada kedua orang tua, kakak, adik, dan keluarga yang selalu mendo' akan dan memberi dukungan baik moral maupun materi kepada penulis. Kepada Ibu Siti Sunendiari, Dra., M.Si. yang telah memberi bimbingan kepada penulis hingga penelitian ini selesai. Dosen-dosen Program Studi Statistika Universitas Islam Bandung yang telah banyak memberikan ilmu pengetahuan. Semua pihak yang telah hingga penelitian ini selesai.

\section{Daftar Pustaka}

[1] Agresti, A. (2002). An Introduction to Categorical Data Analysis. (Second Edition). New York: John Wiley \& Sons.

[2] BPS. (2019). Statistika Perumahan Provinsi Jawa Barat Tahun 2019. Bandung: BPS Provinsi Jawa Barat.

[3] Cameron, A.C. and Trivedi, P.K. (1998). Regression Analysis of Count Data. New York: Cambridge University Press.

[4] Dinkes. (2019). Profil Kesehatan Jawa Barat tahun 2019. Bandung: Dinas Kesehatan Provinsi Jawa Barat.

[5] Herdiani, E.T., \& Amran. (2007). Seleksi model multinomial logit melalui akaike's information criterion (AIC). Jurnal Matematika, Statistika \& Komputasi, 4(1), 47.

[6] Hilbe, J.M. (2011). Negative Binomial Regression. (Second Edition). New York: Cambridge University Press.

[7] Kemenkes. (2019). Penanggulangan Kusta. Jakarta: Menteri Kesehatan Republik Indonesia.

[8] McCullagh, P., and J.A. Nelder (1983). Generalized Linear Models. (Second Edition). New York: Chapman and Hall.

[9] Ridwan, M., \& Sunendiari, S. (2021). Mendeteksi dan Mengatasi Multikolinieritas pada Data Penelitian Diabetes Melitus Wanita Suka Indian Tahun 2018. Jurnal Statistika, 7(1), 64-70.

[10] Tango, T. dan Takahashi, K. (2005). A flexibly shaped spatial scan statistic for detecting clusters. International Journal of Health Geographics, 4(11), 1-15. 